\title{
Faecal sulphatase in health and in inflammatory bowel disease
}

\author{
J M RHODES, RUTH GALLIMORE, E ELIAS, AND J F KENNEDY
}

\begin{abstract}
From the Department of Medicine, Queen Elizabeth Hospital, Birmingham and Department of Chemistry, University of Birmingham, Birmingham
\end{abstract}

SUMMARY Histochemical studies have shown a relative depletion of colonic sulphated mucins (sulphomucins) in active ulcerative colitis. One possible explanation for this could be desulphation by bacterial sulphatases. Studies have therefore been done to determine whether normal faeces contain sulphatase and if so to determine whether this activity is increased in ulcerative colitis. Using a fluorimetric assay considerable sulphatase activity $(>0.3 \mathrm{IU} / \mathrm{g}$ pellet weight) was found in bacteria free filtrates of the homogenates of nine of 17 faecal samples from healthy controls. This sulphatase activity had an alkaline $\mathrm{pH}$ optimum (pH 8.5-9.5). A similar range of faecal sulphatase activity with a similar $\mathrm{pH}$ optimum was found in samples from patients with ulcerative colitis $(n=39)$ and Crohn's disease $(n=17)$ and there was no correlation with disease activity in either disease. This faecal sulphatase activity may be involved in the degradation of colonic mucus and merits further study but these findings do not explain the relative depletion of colonic mucosal sulphomucins in ulcerative colitis.

In health a large proportion of the human colonic mucus is sulphated ${ }^{1}$ but in active ulcerative colitis and Crohn's disease histochemical studies have shown a relative depletion of colonic sulphomucins. ${ }^{2}$ The normal colonic flora contains bacteria which produce glycosidases capable of degrading colonic mucins ${ }^{3}$ but it is not known whether sulphatase producing bacteria are also present. It is quite likely that they are as rat faeces have been shown to contain sulphatase activity ${ }^{4}$ which is abolished by prior antibiotic treatment and which seems to be produced mainly by a lactobacillus. ${ }^{6}$

There are several reasons why sulphatase production by faecal organisms might be important in the pathogenesis of colonic disease. If the sulphatases were capable of desulphating colonic mucus they would alter its charge and hence its physical properties and also probably increase its susceptibility to further degradation by bacterial glycosidases. ${ }^{7}$ Sulphatases might also activate toxins such as lithocholic acid which are detoxified by sulphation. ${ }^{8}$ Assays of faecal sulphatase activity have therefore been undertaken on samples obtained from patients with inflammatory bowel disease and from healthy controls.

Address for correspondence: Dr J M Rhodes, Department of Medicine, Queen Elizabeth Hospital, Edgbaston, Birmingham B15 2TH.

Received for publication 22 June 1984

\section{Methods}

SUBJECTS

A faecal sample was obtained from each of 17 healthy control subjects (university students) and 39 samples were obtained from 32 patients with ulcerative colitis and 17 samples from 14 patients with Crohn's disease. Of the ulcerative colitis samples seven were from patients in remission, six from patients with mild disease, 15 moderate and 11 severe disease as defined by clinical criteria. ${ }^{9}$ Of the Crohn's disease samples four were from patients in remission, four from patients with mild disease, four moderate, and five severe disease judged by similar clinical criteria. ${ }^{10}$ Nine of the Crohn's disease patients had ileo-colonic disease, four had colonic disease only and one had ileal disease only. Only six of the patients with ulcerative colitis and three of the patients with Crohn's disease were hospital inpatients at the time of the study. No patients had received antibotics within the previous month but 21 of the ulcerative colitis samples and three of the Crohn's disease samples were collected from patients receiving sulphasalazine. The faecal samples were collected in $20 \mathrm{ml}$ sterile universal containers and frozen at $-20^{\circ} \mathrm{C}$ within four hours of voiding. Preliminary studies have shown that faecal sulphatase is stable at $-20^{\circ} \mathrm{C}$ for at least four weeks. 
ENZYME ASSAYS

Three aliquots, each approximately $0.5 \mathrm{~g}$ were taken from each faecal sample, thawed and homogenised in $30 \mathrm{ml} 0 \cdot 2 \mathrm{M}$ Tris acetate buffer using a loose fitting glass homogeniser. Assays were performed on each sample using Tris acetate buffer at pH's 5.5, $6 \cdot 5,7 \cdot 5$ and $8 \cdot 5$. The faecal homogenates were then centrifuged at $15000 \mathrm{~g}$ for 30 minutes at $5^{\circ} \mathrm{C}$. The resulting pellets were weighed and the supernatants filtered through a series of prefilters culminating in a $0.22 \mu \mathrm{m}$ pore diameter filter (Millipore, UK) to obtain a bacteria free filtrate. Two aliquots of each filtrate were assayed fluorimetrically ${ }^{11}$ for sulphatase activity using $0.02 \mathrm{mM}$ 4-methyl umbelliferyl sulphate (Sigma) as substrate. Assays were performed over 10 minutes at $37^{\circ} \mathrm{C}$, inhibited by the addition of $0.1 \mathrm{ml} 1.33 \mathrm{M}$ glycine buffer $\mathrm{pH} 10.7$ and fluorescence estimated immediately using an Aminco-Bowman spectrophotometer at $365 \mathrm{~nm}$ extinction, $450 \mathrm{~nm}$ absorbance. For each sample the results obtained at each $\mathrm{pH}$ represent the mean of six readings. Mean variation between aliquots from the same faecal sample was $4 \%$. Enzyme activity was expressed as $\mu \mathrm{mol}$ methyl umbelliferone released/minute (IU)/g pellet weight. The results were expressed in this way to avoid misleading alterations in enzyme concentration that might otherwise result from a dilutional effect of diarrhoea.

\section{Results}

Sulphatase activity $>0.3 \mathrm{IU} / \mathrm{g}$ pellet weight was detectable at $\mathrm{pH} 8.5$ in nine of 17 normal faecal samples, 12 of 39 ulcerative colitis samples and six of 17 Crohn's disease samples. In all samples tested from control subjects and patients with ulcerative colitis or Crohn's disease the faecal sulphatase had an alkaline $\mathrm{pH}$ optimum ( $\mathrm{pH} 8 \cdot 5-9.5)$ (Fig. 1). There was no significant difference overall between

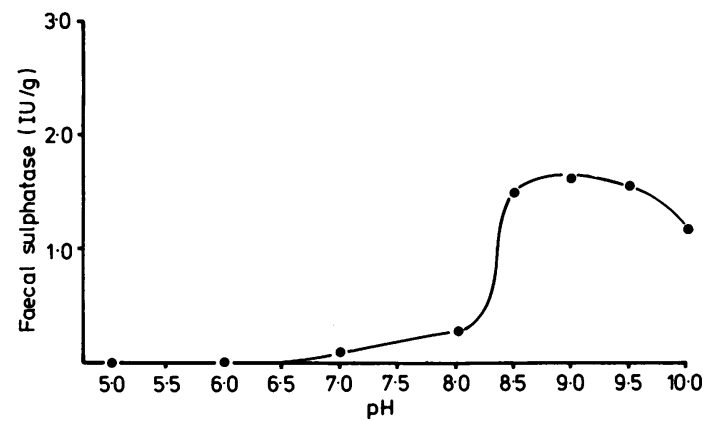

Fig. 1 Sulphatase pH curve for a normal faecal sample.

faecal sulphatase activity in samples obtained from the normal controls and the samples obtained from patients with ulcerative colitis or Crohn's disease. (Fig. 2, Table). Although several high faecal sulphatase values were recorded in patients with active ulcerative colitis there was no obvious trend towards increased faecal sulphatase in more active disease in either ulcerative colitis or Crohn's disease. Little or no sulphatase activity was detectable in any of the samples tested at $\mathrm{pH} 5.5$ or 6.5 (Table 1). In ulcerative colitis there was no significant difference in faecal sulphatase activity between those patients receiving sulphasalazine $(0.75 \pm 1.97 \mathrm{IU} / \mathrm{g}$ at $\mathrm{pH} 8.5$, mean $\pm \mathrm{SD})$ and those not $(1 \cdot 16 \pm 2 \cdot 19 \mathrm{IU} / \mathrm{g}$ at $\mathrm{pH} 8 \cdot 5$, mean $\pm \mathrm{SD})$.

\section{Discussion}

This study shows that sulphatase activity is commonly present in normal human faeces. The sulphatase has an alkaline $\mathrm{pH}$ optimum (between $\mathrm{pH} 8.5$ and $\mathrm{pH} \mathrm{9.5)} \mathrm{which} \mathrm{makes} \mathrm{it} \mathrm{probable} \mathrm{that} \mathrm{it}$ is bacterial in origin, like the rat faecal sulphatase previously reported, ${ }^{6}$ as the lysosomal sulphatase

Table Faecal sulphatase at pH 5.5-8.5 in normal controls and patients with ulcerative colitis and Crohn's disease

\begin{tabular}{|c|c|c|c|c|c|c|c|c|}
\hline & \multicolumn{2}{|c|}{$p H 5.5 \mathrm{IU} / \mathrm{g}$} & \multicolumn{2}{|c|}{$p H 6.5 I U / g$} & \multicolumn{2}{|c|}{$p H 7.5 \mathrm{IU} / \mathrm{g}$} & \multicolumn{2}{|c|}{$p H 8.5 \mathrm{IU} / \mathrm{g}$} \\
\hline & Median & Range & Median & Range & Median & Range & Median & Range \\
\hline Normal subjects $(n=17)$ & $0 \cdot 00$ & $0.00-0.02$ & $0 \cdot 02$ & $0 \cdot 00-0 \cdot 21$ & $0 \cdot 13$ & $0 \cdot 00-0 \cdot 51$ & $0 \cdot 13$ & $0 \cdot 00-2 \cdot 18$ \\
\hline $\begin{array}{l}\text { UC inactive }(n=7) \\
\text { Mild }(n=6) \\
\text { Moderate }(n=15) \\
\text { Severe }(n=11)\end{array}$ & $\begin{array}{l}0.00 \\
0.01 \\
0 \cdot 00 \\
0.00\end{array}$ & $\begin{array}{l}0.00-0.07 \\
0.00-0.09 \\
0.00-0.06 \\
0.00-0.14\end{array}$ & $\begin{array}{l}0.01 \\
0.10 \\
0.02 \\
0.00\end{array}$ & $\begin{array}{l}0.00-0.16 \\
0.00-0.24 \\
0.00-0.28 \\
0.00-0.45\end{array}$ & $\begin{array}{l}0 \cdot 16 \\
0 \cdot 14 \\
0 \cdot 12 \\
0 \cdot 10\end{array}$ & $\begin{array}{l}0.05-0.38 \\
0.00-0.56 \\
0.00-2.45 \\
0.00-2.75\end{array}$ & $\begin{array}{l}0 \cdot 13 \\
0 \cdot 20 \\
0 \cdot 22 \\
0 \cdot 08\end{array}$ & $\begin{array}{l}0 \cdot 04-0.97 \\
0 \cdot 00-3 \cdot 11 \\
0 \cdot 00-8 \cdot 77 \\
0 \cdot 00-9 \cdot 11\end{array}$ \\
\hline $\begin{array}{l}\text { CD inactive }(n=4) \\
\text { Mild }(n=4) \\
\text { Moderate }(n=4) \\
\text { Severe }(n=5)\end{array}$ & $\begin{array}{l}0.01 \\
0.00 \\
0.00 \\
0.00\end{array}$ & $\begin{array}{l}0.00-0.04 \\
0.00-0.01 \\
0.00-0.05 \\
0.00-0.03\end{array}$ & $\begin{array}{l}0.05 \\
0.02 \\
0.05 \\
0.00\end{array}$ & $\begin{array}{l}0.00-0.16 \\
0.00-0.09 \\
0.00-0.13 \\
0.00-0.07\end{array}$ & $\begin{array}{l}0.16 \\
0 \cdot 16 \\
0 \cdot 09 \\
0.00\end{array}$ & $\begin{array}{l}0.02-0.84 \\
0.06-0.53 \\
0.00-0.59 \\
0.00-0.56\end{array}$ & $\begin{array}{l}0 \cdot 15 \\
0.33 \\
0 \cdot 18 \\
0 \cdot 04\end{array}$ & $\begin{array}{l}0 \cdot 09-1 \cdot 45 \\
0 \cdot 17-1 \cdot 27 \\
0 \cdot 00-3 \cdot 24 \\
0 \cdot 00-2 \cdot 39\end{array}$ \\
\hline
\end{tabular}



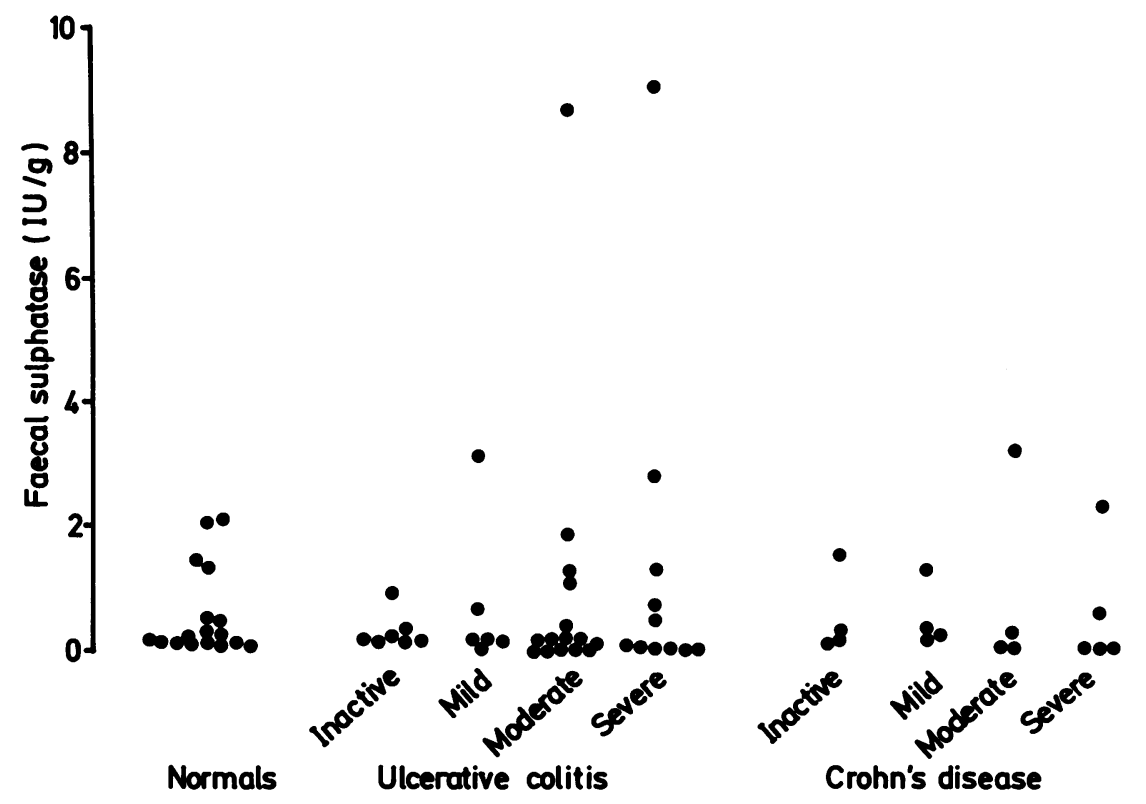

Fig. 2 Faecal sulphatase assayed at pH 8.5 in normal controls and patients with ulcerative colitis and Crohn's disease.

arylsulphatase $\mathrm{A}$ and $\mathrm{B}$ have acidic $\mathrm{pH}$ optima as do human $\mathrm{N}$-acetyl glucosamine 6-sulphate sulphatase and $\mathrm{N}$-acetyl galactosamine 6-sulphate sulphatase while the microsomal arylsulphatase $\mathrm{C}$ is insoluble and seldom detected in body fluids. ${ }^{12} \mathrm{~A}$ large number of bacteria are known to produce sulphatases particularly the Enterobacteriaceae including strains of Klebsiella, Escherichia, Salmonella and Citrobacter and most of these sulphatases have neutral or alkaline $\mathrm{pH}$ optima. ${ }^{13}$

Sulphatases capable of acting on the 4-me umbelliferyl-sulphate substrate used in this study may not necessarily be capable of desulphating colonic mucus but it is probable that some at least are capable of this as histochemical studies show that the rectal mucus becomes desulphated if rectal biopsies are incubated in faecal extracts prepared in a similar way to those used in this study. ${ }^{4}$ Although the $\mathrm{pH}$ optimum of the total faecal sulphatase activity is higher than normal or colitic faecal $\mathrm{pH}$ (5.5-6.5 approximately) these histochemical studies showed that faecal extracts are able to desulphate colonic mucus at pH 5.5. It is also known that some bacteria produce sulphatases which desulphate lithocholate sulphate ${ }^{15}$ liberating lithocholic acid which is potentially toxic to colonic mucosa.

In this study similar levels of sulphatase activity were found in faeces from normal controls and from patients with ulcerative colitis or Crohn's disease although a small number of samples from patients with active ulcerative colitis contained considerably greater sulphatase activity. The reduced sulphation of colonic mucus shown histochemically in ulcerative colitis ${ }^{2}$ in the absence of increased faecal sulphatase activity could be because of either increased susceptibility of the mucus to desulphation by bacteria or of decreased sulphation during mucus synthesis.

The presence in faeces of sulphatase activity which has the potential to desulphate mucus and toxins normally inactivated by sulphation could be pathogenically important in colonic disease.

This work was carried out with the help of a grant from the Birmingham Central District Endowment Fund.

\section{References}

1 Filipe MI. Mucins in the gastrointestinal epithelium: a review. Invest Cell Pathol 1979; 2: 195-216.

2 Ehsanullah M, Filipe MI, Gazzard B. Mucin secretion in inflammatory bowel disease: correlation with disease activity and dysplasia. Gut 1982; 23: 485-9.

3 Hoskins LE, Boulding ET. Mucin degradation in human colon ecosystems. Evidence for the existence and role of bacterial subpopulations producing 
glycosidases as extracellular enzymes. J Clin Invest 1981; 67: 163-72.

4 Lloyd AG. The metabolism of exogenous $\mathrm{N}$-acetyl-Dglucosamine $6-0\left({ }^{35} \mathrm{~S}\right)$ sulfate in the normal rat. Biochem J 1961; 80: 572-8.

5 Lloyd AG. The metabolism of N-acetyl-Dgalactosamine 6-0 $\left({ }^{35} \mathrm{~S}\right)$ sulphate in the rat. Biochim Biophys Acta 1962; 58: 1-6.

6 Large PJ, Lloyd AG, Dodgson KS. Desulphation of D-glucose 6-sulphate by microorganisms. Biochem $J$ 1964; 90: 12p.

7 Mian N, Anderson CE, Kent PW. Neuraminidase inhibition by chemically sulphated glycopeptides. Biochem J 1979; 181: 377-85.

8 Cowen AE, Korman MG, Hofmann AF. Metabolism of lithocholate in healthy man 1 . Biotransformation and biliary excretion of intravenously administered lithocholate, lithocholylglycine and their sulfates. Gastroenterology 1975; 69: 59-66.
9 Truelove SC, Witts LJ. Cortisone in ulcerative colitis: Final report on a therapeutic trial. Br Med J 1955; 2: $1041-8$.

10 DeDombal FT, Burton IL, Goligher JC. The early and late results of surgical treatment for Crohn's disease. $\mathrm{Br}$ J Surg 1971; 58: 805-16.

11 Jordan TW, Heiss F, Monk B, Nicholls J. The 4-methylumbelliferone sulphate sulphatases of human tears. J Inher Metab Dis 1980; 3: 55-60.

12 Farooqui AA. Sulfatases, sulfate esters and their metabolic disorders. Clin Chim Acta 1980; 100: 285-99.

13 Dodgson KS, White GF, Fitzgerald JW. Sulfatases of microbial origin. CRC 1982; 133-58.

14 Rhodes JM, Black RR, Gallimore R', Savage A. Histochemical demonstration of faecal sulphatase activity [Abstract] Gut 1983; 24: A1009.

15 Imperato TJ, Wong CG, Chen LJ, Bott RJ. Identification of bile salt sulfatase in pseudomonas aeroginosa. Gastroenterology 1976; 71: 109A. 